Historic, Archive Document

Do not assume content reflects current scientific knowledge, policies, or practices. 

INDFXED

SPRING BARGAIN LIS'T and Clean Up Sale of Our

SURPLUS

\section{Spring of 1916}

\section{OZARK} NURSERY

co.

\section{Tahlequah, Okla.}

TN PRESENTING this, our Annual Spring Bargain List, we want 1 to thank our customers of the past seasons, and assure you that the stock offered in this list is first class in every respect, and will be found as satisfactory as it has been in previous years.

We grow our own Nursery Stock and decided to give our customers a chance to buy our surplus each spring at a bargain. We have met with such success that we are extending this opportunity to new territories and hope to establish new customers.

Terms of sale: Cash with your order.

You cannot buy Nursery Stock from any of our agents at these prices, but the cash must be sent direct to us with your order.

We will pay the express on all orders of $\$ 10.00$ or more:

All stock will be carefully packed, and delivered to freight, express or postoffice. See Parcel Post table on back to find how much to send for postage.

If you are not satisfied with stock when received, return at our expense and get your money back.

\section{REFERENCES: \\ FIRST NATIONAL BANK Tahlequah, Okla. \\ FIRST STATE BANK Tahlequah, Okla. \\ Or any business firm in Tahlequah,}

\section{CERTIFICATE OF NURSERY INSPECTION}

\section{OKLAHOMA CITY, OKLA.. A TYG.23, 1915.}

This is to Certify That in accordance with Senate Bill No. 342 of the Session Laws of 1914-15, the Nursery Stock, consisting of 30 acres, now growing for sale by Ozark Nurser.y Company, of Tahlequah. Oklahoma, has been inspected by a duly authorized Inspector and found to be apparently free from dangerously injurious insects and plant disease. Invalid after October 1, 1916.

Countersigned: F. M. GAULT,

President State Board Agriculture. 


\section{FREF WITH YOUR ORDER}

In order to get the names of more property owners on our books we offer you 12 small grape vines for the names and addresses of 12 of vour neighbors who own their own homes, if sent with your order for nursery stock.

\section{PARCEL POET}

Parcel Post is one of the best ways to send out small orders of trees, and insures prompt delivery with the lesst possible trouble to you. We give below a table showing you how much postage to send extra in making your order:

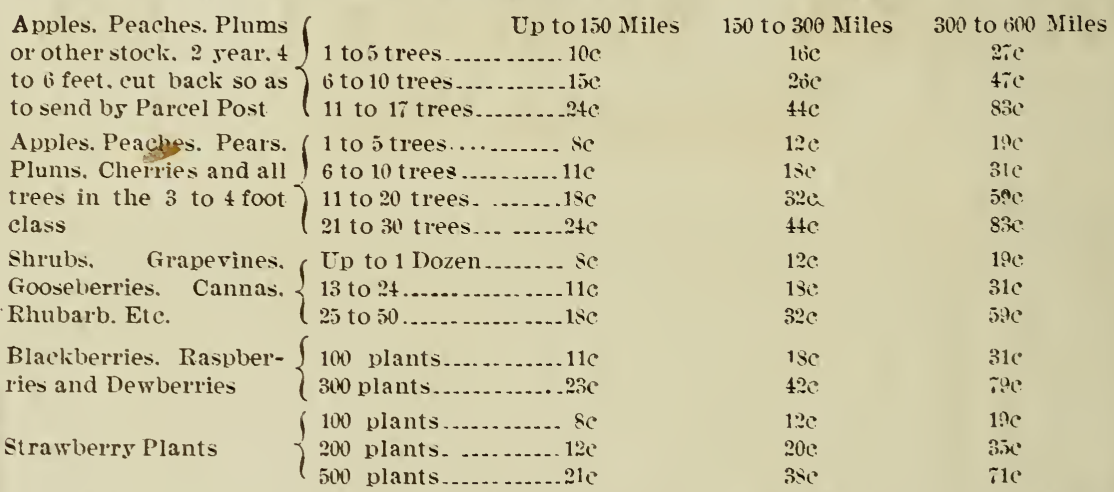

Larger orders may be sent the first 150 miles, and if you order sereral different things all sent in one bundle it will be less than these figures. however we will return the extra postage, if there is any,

\section{SWEET POTATO SLIPS in season}

On and after the 20th of April we offer Sweet Potato slips at the following prices

100 delivered by Parcel Post 210 delivered by Parcel Post Up to 150 Miles Over 150 Miles

500 delivered by Parcel Post

$\begin{array}{lr}\$ .30 & \$ .30 \\ .50 & 5.5 \\ 1.15 & 1.20 \\ 2.25 & 240 \\ 4.40 & 475 \\ \ldots \ldots \ldots & 17.50\end{array}$

2.000 delivered by Parcel:Post

10, C00 H. O B. Tahlequah by express. ..........

If you are nearer to Tahlequah than is Oklahoma City, Okla; Ft. Scott, Kansas; Springfield, Mo.; Little Rock, Ark; or Paris, T€xas, you are less than 150 miles; if you are outside this circuit it is over 100 miles bv Parcel Post.

We will have the following varieties-most of the first numbers and fewest of the last. In making your order we would like to have yon give a secrind choice so that if we are running short on vour first choice we can send part of your order in your second choice and thereby fill your order more promptly.
1. Southern Queen
5. Pink Yam
9. Yellow Jersey
2. Nancy Hall
6. Red Nansemond
I0. Dooley Yam
3. Yellow Yam
i. Georgia Yam
11. Pumpkin Yam
4. Mississippi Yam
8. Red Caba Yam

Last year we were not able to keep up with the demand, and could not fill all our orders. We have doubled our supply for this season and expect to be able to fill all orders, large or small. We expect to sell over one million slips. Let us have your order. 


\section{SPRING BARGAIN LIS'T and Clean Up Sale of Our SURPLUS STTOCK Spring of 1916 OZARK NURSERY CO. Tahlequah, Okla.}

IN PRESENTING this, our Annual Spring Bargain List, we want 1 to thank our customers of the past seasons, and assure you that the stock offered in this list is first class in every respect, and will be found as satisfactory as it has been in previous years.

We grow our own Nursery Stock and decided to give our customers a chance to buy our surplus each spring at a bargain. We have met with such success that we are extending this opportunity to new territories and hope to establish new customers.

Terms of sale: Cash with your order.

You cannot buy Nursery Stock from any of our agents at these prices, but the cash must be sent direct to us with your order.

We will pay the express on all orders of $\$ 10.00$ or more.

All stock will be carefully packed, and delivered to freight, express or postoffice. See Parcel Post table on back to find how much to send for postage.

If you are not satisfied with stock when received, return at our expense and get your money back.

\section{FIRST NATIONAL BANK \\ Tahlequah, Okla. \\ FIRST STATE BANK \\ Tahlequah, Okla. \\ Or any business firm in Tahlequah,}

\section{CERTIFICATE OF NURSERY INSPECTION}

OKLAHOMA CITY, OKLA., A EG.23, 1915.

This is to Certify 'That in accordance with Senate Bill No. 342 of the Session Laws of 1914-15, the Nursery Stock, consisting of 30 acres, now growing for sale by Ozark Nursery Company, of Tahlequah, Oklahoma, has been inspected by a duly authorized Inspector and found to be apparently free from dangerously injurious insects and plant disease. Invalid after October 1, 1916.

President State Board Agriculture. 


\section{FREE WITH YOUR ORDER}

In order to get the names of more property owuers on our books we offer you 12 small grape vines for the names and addresses of 12 of your neighbors who own their own homes, if sent with your order for nursery stock.

\section{PARCEL POST}

Parcel Post is one of the best wars to send out small orders of trees, and insures prompt delivery with the lenst possible tronble to you. We give below a table showing you how much postage to send extra in making your order:

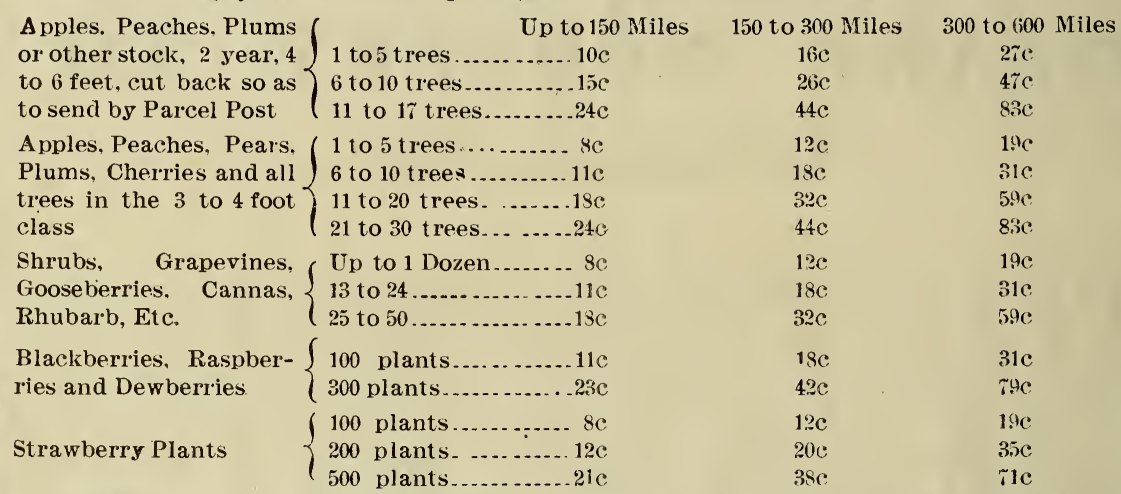

Larger orders may be sent the first 150 miles, and if you order sereral different things all sent in one bundle it will be less than these figures, however we will return the extra postage, if there is ans,

\section{SWEET POTATO SLIPS in season} prices

On and after the 20th of April we offer Sweet Potato slips at the following

$\begin{array}{rcr}100 \text { delivered by Parcel Post } & \$ .30 & \$ .30 \\ \text { 200 delivered by Parcel Post } & .50 & 5.5 \\ 500 \text { delivered by Parcel Post } & 1.15 & 1.20 \\ \text { 1,000 delivered by Parcel Post } & 2.25 & 240 \\ \text { 2.000 delivered by Parcel:Post } & 4.40 & 475 \\ 10, \text { C00 F.. O B. Tahlequah by express. . .......\$17.50 } & \end{array}$

If you are nearer to Tahlequah than is Oklahoma City, Okla; Ft. Scott, Kausas; Springfield, Mo.; Little Rock, Ark; or Paris, Texas, you are less than 150 miles; if you are outside this circuit it is over 150 miles bv Parcel Post.

We will have the following varieties-most of the first numbers and fewest of the last. In making your order we would like to have you give a secrind choice so that if we are running short on vour first choice we can send part of your order in your second choice and thereby fill your order more promptly.
1. Southern Queen
5. Pink Yam
6. Red Nansemond
9. Yellow Jersey
2. Nancy Hall
7. Georgia Yam
10. Dooley Yam
3. Yellow Yam
11. Pumpkin Yam
4. Mississippi Yam

8. Red Cuba Yam

Last year we were not able to keep up with the demand, and could not fill all our orders. We have doubled our supply for this season and expect to be able to fill all orders, large or small. We expect to sell over one million slips. Let us have your order.

\section{OZARI NURSERY COMPANY TAHLEQUAH, OKI.AHOMA}

